\title{
The Influence of Problem Based Learning (PBL) Model Collaborative and Learning Motivation Based on Students' Critical Thinking Ability Science Subjects in Class V State Elementary School 105390 Island Image
}

\author{
Siti Khairani ${ }^{1}$, Retno Dwi Suyanti ${ }^{2}$, Daulat Saragi ${ }^{3}$ \\ ${ }^{1,2,3}$ Universitas Negeri Medan, Indonesia \\ sitikhairani3011@gmail.com
}

\begin{abstract}
The study aims to determine the influence of the Problem Based Learnimg (PBL) learning model and the motivation to students critical thinking skills, as well as the interaction between learning models and the motivation to learn from students critical thinking skills. This study was conducted at SD Negeri 105390 in the even semester of the 2019/2020 school year. The population in this study is a class V student of elementary school 105390 Island pictures numbering at 55 people. Sampling is carried out in total, i.e. $V-A$ and V-B classes. The $V-B$ class as an experimental class taught with a collaborative problem-based learning (PBL) model with the number of students 28 people. As for the control class is taught by a direct instruction model elected class $V$-A with the number of students as many as 27 people. This type of research includes research quasi experiments with $2 \times 2$ factorial design with analytical techniques variance (ANAVA) 2 lines. Based on the results of the analysis and research findings from the field obtained several conclusions that are answers to questions on the problem formulation, among them the critical thinking ability of students taught with a collaborative Problem-based learning model better than students taught with a direct learning model ( sig. $=0.000<$ 0.05), a student's critical thinking ability of high motivation is better than a low-motivation student (sig. $=0.01<0.05$ ), and there is interaction between the two learning models with a level of motivation in influencing students ' critical thinking ability ( sig. $=0.02<0.05$ ).
\end{abstract}

Keywords

the ability of critical thinking; motivation; a collaborative problem based learning (PBL)

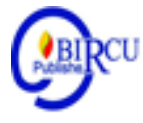

\section{Introduction}

The awareness of the importance of education is now increasing. Education is the most important basic capital for preparing human beings who have quality, namely those who believe and fear the Almighty God, have a noble character, are healthy, knowledgeable, capable, creative, independent, and become democratic and responsible citizens (In RI Law No. 20 of 2003). In order for the world of education to increase, many things must be improved. Starting from improving the curriculum, improving educational facilities and infrastructure, training and increasing teacher qualifications and using various learning models by teachers. Pohan (2020) states that at school, from elementary to secondary school or even college, students undergo, practice, and experience the learning process of various knowledge and skills. 
The teacher's role is very important in the success of his students. Conceptually, the teacher's job includes three main functions: 1) leader; 2) learning manager; and 3) organizers (Tawil and Liliasari, 2014: 1). Therefore, the teacher must be more careful in developing strategies, methods, and skills so that learning objectives can be achieved and implemented properly. Natural Science in elementary schools is one of the main subjects in the educational curriculum. Science learning in elementary schools is expected to increase students' awareness in maintaining, maintaining and preserving the environment so that students can maintain the balance of nature and take advantage of the natural environment for their daily lives. Science or Science is a human effort to understand the universe through proper observation on the target, and using procedures, and is explained by reasoning so as to get a conclusion (Susanto, 2013: 167). According to Simanjuntak (2020) the teacher is a very important factor in determining the success of the learning process, therefore the teacher must be able to increase student learning motivation so that students play an active role in the learning process so that they are expected to achieve good quality education. The science learning process requires student activeness and creativity which students will get with direct experience. According to Patta Bundu (2006: 3) science learning in the majority in elementary schools so far, 1) there are still many teachers who really emphasize learning on the memory factor, 2) very lack of practicum implementation, and 3) the focus of presentation with lectures which results in very limited activities, nothing more than listening and copying. This is in line with Winda's (2016: 2) research that science learning in class does not fully involve students actively. This was also found in preliminary observations at SDN 105390 Pulau Gambar on July 29, 2019, that science learning tended to listen to teachers explain and work on the questions in each student's handbook. Experiments in student books that should be demonstrated or practiced are only read by students in turn. This contrasts with the opinion of Susanto (2013: 170), namely that science learning in elementary schools is carried out by simple investigations instead of memorizing a collection of science concepts.

Science learning using the lecture method will result in students becoming passive so that it will affect the science learning achievement and the success of science learning.Based on observations made on July 29, 2019, the teaching and learning process is still a teacher center. This can be seen because during the teaching and learning process the teacher explains the subject matter in front of the class. Students just sit and listen to the teacher's explanation. At the end of the new explanation, the teacher asks students about the material they have just explained. But students are reluctant to ask questions and just keep quiet. In fact, there were several children who were alone at their table. And it is feared that this will affect the scores obtained by students.

This can happen because the learning model chosen by the teacher has not been able to invite students to take an active role. So that students do not have the desire to learn and find out about the material being taught. Student motivation to study science is still low. The teacher has made remedials to overcome this problem but the retest that is carried out is only for improving the value, not by improving during the learning process. The teacher's ability to make questions for student practice also has an effect because the questions given by the teacher are only at the cognitive level of knowledge, so that students' critical thinking skills are not honed. Rofi'udin (2000) argues that there are complaints about the low criticalcreative thinking skills of elementary school graduates to tertiary institutions in Indonesia, because thinking education has not been handled properly.

Based on the existing problem background, several problems can be identified which can be identified as follows: (1) The teaching and learning process at Primary school No. 
105390 Pulau Gambar is still the teacher center because students have not played an active role in the learning process. (2) The questions given by the teacher are still at the memorization level so that the students' critical thinking skills in solving science questions are still low. (3) The learning model chosen was less precise and less attractive so that the students' learning motivation in class V Primary School No 105390 Pulau Gambar was low. (4) The teacher emphasizes cognitive assessment only so that the activities carried out by students only work on questions. (5) The implementation of practicum is very lacking so that students feel bored when there is material that should be carried out practicum. (6) Class management, especially the arrangement of student seats, is still conventional so that interaction between students is limited. (7) Unavailability of learning media so that the learning process is less attractive so that the motivation to learn Science is still low.

The purpose of this research is to find out (1) To analyze the effect of the collaborativebased Problem Based Learning (PBL) model and direct instruction model on students' critical thinking skills on the Changing of Objects in Primary School No 105390 Pulau Gambar. (2) To analyze the effect of learning motivation on students' critical thinking skills in the material change in the nature of objects in Primary School No 105390 Pulau Gambar. (3) To analyze the interaction of the collaborative-based Problem Based Learning (PBL) model with learning motivation in improving students' critical thinking skills in the material Changing the nature of objects in Primary School No 105390 Pulau Gambar.

\section{Research Method}

The population in this study were 55 students of class V Primary School 105390 Pulau Gambar for the 2019/2020 academic year, consisting of two classes, namely class V-A and class V-B. Sampling was done by total sampling. Two research samples, namely class V-A and V-B. After selecting a class with the aim of seeing the use of a collaborative-based problem based learning (PBL) model, class V-B was selected as an experimental class that was taught with a collaborative-based problem based learning (PBL) model with 28 students. Whereas for the control class, it was taught using direct instruction model, which was selected by class V-A with 27 students. This type of research is a quasi-experimental research (pseudo-experiment), which aims to determine whether there is a result of "something" imposed on students, namely students.

\section{Discussion}

\subsection{Critical Thinking Skills}

Thinking skills are a gift that God has given us to always be grateful for all that He has created. Nur (2011: 7) states that "thinking is a person's ability to analyze, criticize, and formulate conclusions based on careful consideration. Critical thinking skills can be developed through science learning, precisely in elementary schools which focuses on systems, structures, concepts, principles, and tight ties between one element and another (Maulana, 2008: 39). Furthermore, Johnson (2007: 189) found that critical thinking is a hobby of thinking that can be developed by everyone, so this must be taught or applied since elementary school. Thinking skills stated by Iskandar (2009: 86-87) are reflective, critical, and creative reasoning activities that are oriented towards an intellectual which involves the formation of concepts, applications, analysis, synthesis or those resulting from observation, experience, reflection, communication as foundation of a belief (belief) and action. 
Critical thinking is a skill in sorting out which ones are worth a number of ideas or considering a decision (Edward De Bono, 2007). This understanding is in line with the opinion of Kuswana (2011: 24) which explains that critical thinking is an analysis of problem situations through potential evaluation, problem solving, and synthesis of information to determine decisions. Rochaminah (2008: 4) also argues that critical thinking is one of the series in the learning process, for example skilled and active interpretation and evaluation of observation and communication, information, and argumentation. It can be concluded that critical thinking is the ability to evaluate and observe to make decisions. Critical thinking emphasizes understanding the meaning, finding out the cause, and proving it as a consideration in making a decision.

According to Sciven and Paul (1987: 35) critical thinking is the intellectually disciplined process of actively and skilfully conceptualizing, applying, analyzing, synthesizing, and or evaluating information gathered from, or generated by observation, experinces, reflection, reasoning, or communication, as guide to belief and action. In its exemplary form, it is based on universal intellectual values that transcend subject matter divisions, clarity, accuracy, precision, consintency, relevance, sound evidence, good reasons, depth, breadth, and fairness.

Based on the above understanding, critical thinking skills are related to cognitive processes and student motivation to think reflective about a problem. There are six indicators of critical thinking, namely: (1) identifying problems, (2) collecting relevant information, (3) developing alternative problem solving, (4) making conclusions, (5) expressing opinions, and (6) evaluating arguments. The critical thinking indicator is a combination of the opinion of Glaser (Fisher, 2008: 7), and Fisher (2008: 8).

The critical thinking skills can be broken down into the influencing aspects written in table Aspects of Critical Thinking Skills according to Ennis.

Table 1. Aspects of Critical Thinking Skills

\begin{tabular}{|c|c|c|}
\hline No & Aspect & Indicato \\
\hline 1 & Give a simple explanation & $\begin{array}{c}\text { Coalition statements } \\
\text { Ask and answer clarifying } \\
\text { questions }\end{array}$ \\
\hline 2 & Build basic skills & $\begin{array}{c}\text { Assess the credibility of a } \\
\text { source } \\
\text { Researching } \\
\text { Assess research results }\end{array}$ \\
\hline 3 & Make inference & $\begin{array}{c}\text { Reducing and assessing } \\
\text { education } \\
\text { Induction and assess induction } \\
\text { Make and judge valuable } \\
\text { judgments }\end{array}$ \\
\hline 4 & Provide further explanation & $\begin{array}{l}\text { Defines terms } \\
\text { Assess the definition } \\
\text { Identify assumptions }\end{array}$ \\
\hline 5 & Set strategy and tactics. & $\begin{array}{l}\text { Decide on an action } \\
\text { Interact with other people }\end{array}$ \\
\hline
\end{tabular}




\subsection{Motivation to Learn}

Motivation starts with the word motive. There are so many, in fact it is common for people to say "motive" to show why someone is doing something. The word "motive" is defined as an effort to encourage someone to do something. Starting from the word "motive", motivation can be interpreted as a driving force that has become active (Sardiman, 2009: 73). Purwanto (2010: 71) which states that "motivation is a conscious effort to influence a person's behavior so that he moves his heart to act to do something so as to achieve certain results or goals". Clayton Alderfer (in Nashar, 2004: 42) states that learning motivation is the tendency of students to carry out learning activities that are driven by the desire to achieve the best possible achievement or learning outcomes. The same thing was also conveyed by Mc. Donald (in Sardiman, 2009: 73) says that motivation is a change in energy in a person which is marked by the emergence of "feelings" and is preceded by a response to a goal. There are three important elements contained in the meaning of motivation conveyed by Mc. Donald, namely: (1) motivation initiates energy changes in each individual human being. The development of motivation will bring some energy changes in the "neurophysiological" system that exists in the human organism because it involves changes in human energy, its appearance will involve human physical activity. (2) motivation is characterized by the emergence of a person's feeling, affection. Motivation is relevant to psychological, affective and emotional issues that can determine human behavior. (3) motivation will be stimulated because of the purpose. Motivation does come from within humans, but it emerges because it is stimulated / driven by the presence of other elements in this case is a goal that concerns needs. Lumbantobing (2020) states that good motivation in learning shows good results. In other words, by having high motivation, it produces good achievements. In learning activities, motivation can be said to be the overall driving force within students which ensures the continuity of learning activities and gives direction to learning activities, so that the desired goals can be achieved. If we look at the test results for each dimension, the intrinsic dimension and the extrinsic dimension are contradictory. However, the great thing is that when these dimensions combine to form participation motivation, it turns out that intrinsic motivation becomes meaningful.

Sardiman (2009: 75) states that what is meant by learning motivation is the overall movement within students that causes learning activities, which ensures the continuity of learning activities and which gives direction to learning activities, so that the goals desired by the learning subjects are achieved. It is said as a whole because in general there are several motives that jointly move students to learn. Learning outcomes will be optimal if there is the right motivation. The same thing was also conveyed by Raymond (2004: 99) that learning motivation is a value or an encouragement to learn. And it can be concluded that learning motivation is an effort made to change a person's behavior in order to achieve a result in learning activities. Motivation can appear by itself in a person and some must be driven by a desired goal.

\subsection{Learning Motivation Function}

Motivation encourages someone to do an activity or job. Likewise, when studying, motivation is needed. Learning outcomes will be optimal if there is motivation. The more precise the motivation, the more successful the lesson will be. The same thing was also conveyed by Djamarah (2002: 123), there are three functions of motivation, namely: (1) motivation as an action driver. Motivation serves as a driving force to influence what attitudes students should take in order to learn, (2) motivation as a driving force for actions. The psychological urge to give birth to attitudes towards students is an unstoppable force, which then manifests in the form of psychophysical movements, (3) motivation as action 
direction. Students who have motivation can select which actions to do and which actions to ignore. According to Wulandari (2020) learning motivation can describe the processes that can bring up and encourage behavior, provide direction and purpose of behavior and can determine whether or not good in achieving goals so that the greater the motivation will be greater learning success.

According to Istarani \& Pulungan (2015: 58), the function of motivation in learning is: (1) buying strength in learning power, (2) providing clear learning directions, (3) being able to overcome obstacles, (4) realizing independent learning, ( 5) encouraging continuous learning, (6) fostering a desire for achievement, (7) increasing the quality of learning.

The function of learning motivation according to Sardiman (2009: 85) is as follows: "(1) encouraging humans to act, so as a driving force or motor that releases energy, (2) determining the direction of action, namely towards the goal to be achieved, (3) selecting actions, namely determining what actions must be carried out in harmony in order to achieve the goal by setting aside actions that are not useful for that goal ".

\subsection{Indicators of Learning Motivation}

According to Abin Syamsudin M (1996: 121) what we can do to increase learning motivation is to identify several indicators in certain stages. Motivational indicators include: 1) Duration of activities, 2) Frequency of activities, 3) Presistence of activity objectives, 4) Persistence, persistence and ability to face activities and difficulties to achieve goals, 5) Dedication and sacrifice to achieve goals, 6) Level aspirations to be achieved with the activities carried out, 7) Level of qualification of achievement, 8) Direction of attitude towards activity targets. Meanwhile, according to Uno (2014: 23) argues that the indicators of motivation are as follows: (1) the desire and desire to succeed; (2) encouragement and need in learning; (3) the existence of hopes and aspirations for the future; (4) there is appreciation in learning; (5) there are activities that are interesting in learning; (6) there is a conducive learning environment, allowing a student to learn well.

\subsection{Learning Model}

At this time, various strategies, models and innovative learning media have been developed to be applied in the learning process in elementary schools. Sagala (2009: 175) states that a model can be understood as: "a type or design, description or analogy, a system of assumptions, a simple design of a work system, a description of a possible or imaginary system, and a presentation that is minimized in order to describe and show the nature of the original form. The model has the following stages: (1) Syntax or phasing, is an explanation of the operation of the model. (2) Social systems, how to explain the roles of teachers and learners. (3) The principles of reaction explain how the teacher should behave and respond to student activities. Arends (2008: 24) states that: "a learning model is a plan or pattern that is comprehensive to help students learn certain types of knowledge, attitudes or skills". Based on the above understanding, it can be concluded that the learning model is a plan that has been prepared from the beginning to the end of the learning process. Therefore, the learning model affects the success of students in achieving the goals of learning. A model that can foster student success is a good learning model.

\subsection{Learning Model Problem Based Learning (PBL)}

PBL learning is a teaching approach that uses real-world problems as a context for students to learn critical thinking and problem-solving skills, as well as to acquire essential knowledge and concepts from subject matter (Nurhadi, 2004). According to Moffit, the Problem Based Learning (PBL) model is a learning approach that uses real-world problems 
as a context for students to learn about problem-solving skills and critical thinking skills and to acquire essential knowledge and concepts from subject matter, (Depdiknas, 2002: 12) . Arends (2008: 41) argues that PBL is learning that presents authentic and meaningful problem situations to students, which can serve as a stepping stone for investigation and investigation. Meanwhile, Sanjaya (2009: 214) also argues that PBL can be defined as a series of learning activities that emphasize the process of solving problems faced scientifically. Ibrahim and Nur (in Rusman, 2010: 241) state that PBL is a learning approach that is used to stimulate high-level thinking of students in situations that are oriented towards real-world problems, including learning how to learn. So it can be concluded that PBL is a learning approach that begins with authentic and meaningful problems for students to find information on the solution and problem solving. According to Christensen \& Martin (Killen, 2009: 248), through problem solving activities, students can develop critical thinking skills. In addition, it can help students to develop a deep understanding of the concepts being studied and a better understanding of when and how students apply these concepts.

\subsection{Characteristics of Learning Model Problem Based Learning (PBL)}

According to Amir (2009: 12), the characteristics or characteristics of PBL include: 1) learning begins with giving problems; 2) students in groups actively formulate problems; 3) study and find their own material related to the problem and report the solution. Afcariono (2009: 125) states that one of the characteristics of problem-based learning is to use small groups as a context for learning. Students who are "reluctant" to ask the teacher can ask their friends in their group and other groups. They also do not feel afraid to express their opinion so that it can motivate students to study hard.

\subsection{Objectives of Using Problem Based Learning (PBL) Learning Model}

The main objective of PBL is to enhance students' application of knowledge, problem solving, and self-learning skills that require them to actively articulate, understand, and solve problems. According to Sani (2014: 129) learning with the PBL model allows students to be involved in learning things, including: a) real world problems; b) higher order thinking skills; c) problem solving skills; d) interdisciplinary study; e) self-study; f) learn to dig up information; g) learn to work together; h) learn communication skills. With the Problem Based Learning (PBL) model, students are trained to compose their own knowledge, develop problem-solving skills. In addition, by providing authentic problems, students can shape the meaning of the learning material through the learning process and store it in memory so that it can be used again at any time. Without realizing it, students with the Problem Based Learning (PBL) model the desire of students to learn comes naturally because students become motivated to solve the problems they face while studying. Based on the explanation above, it can be concluded that students' critical thinking skills will be higher in students who have learning motivation. The Problem Based Learning (PBL) model and student learning motivation are expected to affect students' thinking abilities.

\section{Conclusion}

The conclusions of the results of this study are as follows: (1) The critical thinking skills of students who are taught with the collaborative-based problem-based learning model are better than students who are taught with the direct learning model (sig. $=0.000<0.05$ ). Thus, students who were taught with the collaborative-based problem-based learning model obtained higher critical thinking skills scores than students who were taught using the direct 
learning model. This is indicated by the research data, namely the average gain value of students taught by collaborative problem-based learning model of 0.60 , while the average gain value of students taught by direct learning model is 0.21 . (2) The ability to think critically of students who have high motivation is better than students who have low motivation (sig. $=0.01<0.05$ ). Thus, students who have high motivation score higher critical thinking skills than students who have low motivation. This is shown from the research data, namely the group of students who have high motivation get an average value of critical thinking skills of 0.49 , while the group of students who have low motivation get an average value of critical thinking skills of 0.31. (3) There is an interaction between the two learning models and the level of motivation in influencing students' critical thinking skills (sig. $=0.02$ <0.05). Learning models and motivation influence each other to improve students' critical thinking skills. The mean of critical thinking skills that have high motivation in students who are taught with the collaborative-based problem-based learning model is 0.66 while for students who are taught using the direct learning model is 0.30 . The mean of critical thinking skills that have low motivation in students who are taught with the collaborative problembased learning model is 0.52 , while those taught with the direct learning model are 0.09 .

\section{References}

Abin, Syamsudin. (1996). Educational Psychology. Bandung: PT Remaja Rosda Karya.

Afcariono, M. 2009. Application of Problem Based Learning to Improve Students'Thinking Ability in Biology Subjects. (Http://www.wordpress.com/2009/01/01/muchamadafcariono/) Accessed 22 March 2017

Achmad, 2007. Understanding Critical Thinking. Jakarta: Earth Literacy.

Ahlam, Hala, (2014) Impact of Problem-Based Learning on Students Critical Thinking Dispositions, Knowledge Acquisition and Retention, Journal of Education and Practice (5) 14.

Amir, M. Taufiq. 2009. Educational Innovation through Problem Based Learning. Jakarta: Golden

Anderson, W. L \& Krathwohl, R, D. 2001. A Taxonomy for Learning Teaching and Asessing A Revision of Bloom's Taxonomy of Educational Objectives. USA: Addison Wesley Longman.

Arends, R. 2008. Learning To Teach. Translated Soetjio. Learn To Teach. Yogyakarta: Student Library.

Arends, R. 2013. Learning To Teach. Translation Made Frida Yulia. Learn To Teach. Jakarta: Salemba Humanika. Mother, Patta. 2006.

Assessment of Process Skills and Scientific Attitude. Elementary School Science learning. Jakakarta: Ministry of National Education.

Costa, A.L. 1985. Goals for a Critical Thinking Curriculum. In Costa A.L (ed.Developing Mind: A Resource Book for Teaching Thinking. ASCD: Alexandria, Virginia.

Darma, S. 2008. Creativity. Jakarta: Directorate of Education Personnel, Directorate General of Quality Improvement of Education and Education Personnel, Ministry of National Education.

De Bono, E. 2007. The Thinking Revolution. Bandung: PT. Mizan Pustaka. Ministry of National Education. 2002. Summary of Teaching and Learning Activities. Jakarta: Depdiknas.

Djamarah, S.B. 2002. Learning Psychology. Jakarta: Rineka Cipta. 
Evi, Sigit, (2018). The Effectiveness of Problem Based Learning on Science Learning Outcomes in terms of Critical Thinking Ability, Academic Discourse Journal (2) 2.

Fisher, A. (2008). Critical thinking. Jakarta: Erlangga.

Hendrik, Ihtiari, (2016) The Influence of Project Based Learning Learning Model Assisted by Microhydro Power Plant Learning Media on Critical Thinking Ability, Journal of Physics Research and Its Applications (6) 2.

Husnidar, Ikhsan, Syamsul, (2014) Application of Problem Based Learning Model to

Improve Students' Critical Thinking Ability and Mathematical Disposition, Mathematics Didactic Journal (1) 1.

Istarani, \& Pulungan, I. 2015. Educational Encyclopedia Volume I. Medan: Media Persada.

Iskandar (2009), Educational Psychology. Jakarta: Echoes of Persada Press.

Johnson, E.B. 2007. Contextual Teaching And Learning. Making Teaching and Learning Activities Fun and Meaningful. Bandung: Mizan Learning Center.

Joyce, B., Weil, M., Calhoun, E. 2009. Model's Of Teaching (Models - Teaching Models). Learning Library. Yogyakarta.

Kani, (2018) The Effect of Problem-Based Learning on the Creative Thinking and Critical Thinking Disposition of Students in Visual Arts Education, Interdisciplinary Journal of Problem-based Learning (12) 1.

Killen, R. (2009). Effective teaching strategies: lessons from research and practice (5thed). Victoria: Cencage Learning.

King, F.J, Goodson, L \& Rohani, F. (1998). Higher order thinking skills: definition, teaching \& assessment. (online) http://www.cala.fsu.edu/files/higher_or der_thinking_skills.pdf. accessed on 22 March 2017.

Krulik, S. and Rudnick, J.A. 1996. The New Source Book Teaching Reasioning and Problem Solving in Junior and Senior High School. Massachusets, Allyn \& Bacon.

Kuswana, W.S. (2011). Taxonomy of Thinking. Bandung: Rosda. Masaki, A. (2012). Dialogue and Collaboration in Junior High Schools "Learning Community" Practices. Pelita Cooperation between Diknas, Kemenag and Jica.

Lumbantobing, P.A. (2020). The Contribution of Lecturer Pedagogical Competence, Intellectual Intelligence and Self-Efficacy of Student Learning Motivation. Budapest International Research and Critics in Linguistics and Education (BirLE) Journal Vol 3 (1): 564-573.

Maulana, (2008) Metacognitive Approach as an alternative to learning to improve critical thinking skills, Journal of Basic Education (10) 39-46.

Nashar. (2004). The Role of Motivation and Early Ability in Learning Activities. Jakarta: Delia Press.

$\mathrm{Ni}$, Desak, Wayan, (2016) The Effect of Problem Based Learning (Pbl) Learning Model and Project Assessment on Students' Critical Thinking Ability, PGSD Journal (4) 1.

Nur, M. 1998. Development of learning tools in order to support the implementation of the 1994 curriculum in Indonesia. Paper Presented at Improving Teaching Proficiency of Indonesia Junior and Senior Secondary Science Teacher at SEAMEO-RECSAM. Malaysia: Not Published.

Nur, M. (2011). Problem based learning model. Surabaya: Center for Science and Mathematics of UNESA School.

Poedjiadi, A. 1999. Introduction to the philosophy of science for educators. Bandung: Cendrawasih Foundation.

Pohan, A.M., Asmin, and Menanti, A. (2020). The Effect of Problem Based Learning and Learning Motivation of Mathematical Problem Solving Skills of Class 5 Students at 
SDN 0407 Mondang. Budapest International Research and Critics in Linguistics and Education (BirLE) Journal Vol 3 (1): 531-539.

Purwanto, N. 2010. Educational Psychology. Bandung: Youth Rosdakarya.

Rahmad, Hartono, Lilies, (2016) The Influence of the Problem Based Learning (Pbl) Model on the Understanding of Biological Concepts and Students' Critical Thinking Skills about Ecosystems and the Environment in Class X SMA Negeri 1 Sigi, Journal of Science and Technology Tadulako (5) 1.

Simanjuntak, L., Sriadhi, and Saragi, D. (2020). The Effect of Project Based Learning Models and Learning Motivation on Civics Learning Results in 4th Grade Primary School 106163 Percut Sei. Budapest International Research and Critics in Linguistics and Education (BirLE) Journal Vol 3 (3): 1509-1520.

Wulandari, U.N., Ansari, K., and Hadi, W. (2020). The Effect of Cooperative Learning Models and Learning Motivation towards the Skills of Reading Students in Public Elementary School 101883 Tanjung Morawa Sub-district. Budapest International Research and Critics in Linguistics and Education (BirLE) Journal Vol 3 (2): 12091219. 